\title{
The invasive snail Melanoides tuberculata (Müller, 1774) (Gastropoda, Thiaridae) in the lower basin of the Sinú River, Córdoba, Colombian Caribbean
}

\author{
Jorge A. Quirós-Rodríguez ${ }^{1}$, Juan Yepes-Escobar ${ }^{1}$, Gilmar Santafé-Patiño² \\ 1 Grupo de Investigación en Biodiversidad Marina y Costera: BIODIMARC, Universidad de Córdoba. Carrera 6 No. 76-103, Montería, Colombia. \\ 2 Grupo de Investigación Química de los Productos Naturales: PRONAT, Universidad de Córdoba. Carrera 6 No. 76-103, Montería, Colombia. \\ Corresponding author: Jorge A. Quirós-Rodríguez, alexander_quiroz@hotmail.com
}

\begin{abstract}
We record the invasive thiarid snail Melanoides tuberculata (Müller, 1774) for the first time in the lower basin of the Sinú River, Córdoba, Colombia. We counted 2,892 individuals and collected 38 specimens at 4 localities in the basin. The introduction of this species is suspected to have occurred in different ways, but human transport and the aquarium trade are the most probable pathways. The presence of this species in the Sinú River is especially important because of its potential spread to other river basins in the region.
\end{abstract}

\section{Key words}

Invasive species; freshwater molluscs; geographical distribution; regional basins.

\section{Introduction}

The lower basin of the Sinú River in Córdoba, Colombia, is considered a priority area by environmental authorities of the region due to its high productivity and great species richness (CVS 2008, Villadiego et al. 2015). Therefore, it is essential to monitor this wetland, mainly in relation to the introduction of invasive species, as they are considered one of the main causes of biodiversity loss after habitat loss (Vitousek et al. 1996, Leung et al. 2002). The impact of these species on ecosystems causes damage to native species, which can cause a high rate of predation, transmission of diseases and alteration of the structure of trophic levels and their biophysical conditions (Everett 2000, Pino et al. 2010).

Melanoides tuberculata is a highly competitive invasive species and can displace endemic species from the sites where it has been introduced (Fig. 1A); it can also serve as a potential intermediate host of parasites which can affect humans and commercially important fishes (Pointier et al. 1998, Pinto and Melo 2010). This species is native to eastern Africa, eastern Mediterranean, India, southeast Asia, Malaysia, and southern China, and since the 1940s, it has invaded the American continent spreading rapidly throughout the Caribbean (Brown 1994, Rader et al. 2003, Ladd and Rogowski 2012). In Colombia, this gastropod was reported for the first time in the department of Antioquia, at the Joaquín Antonio Uribe Botanical Garden (Areiza et al. 2000, Velásquez et al. 2006, Vergara and Velásquez 2009). There are also records in the department of Huila, in the municipality of Yaguará and in the department of Valle del Cauca, in the municipality of Andalucía (Linares and Vera 2012). 

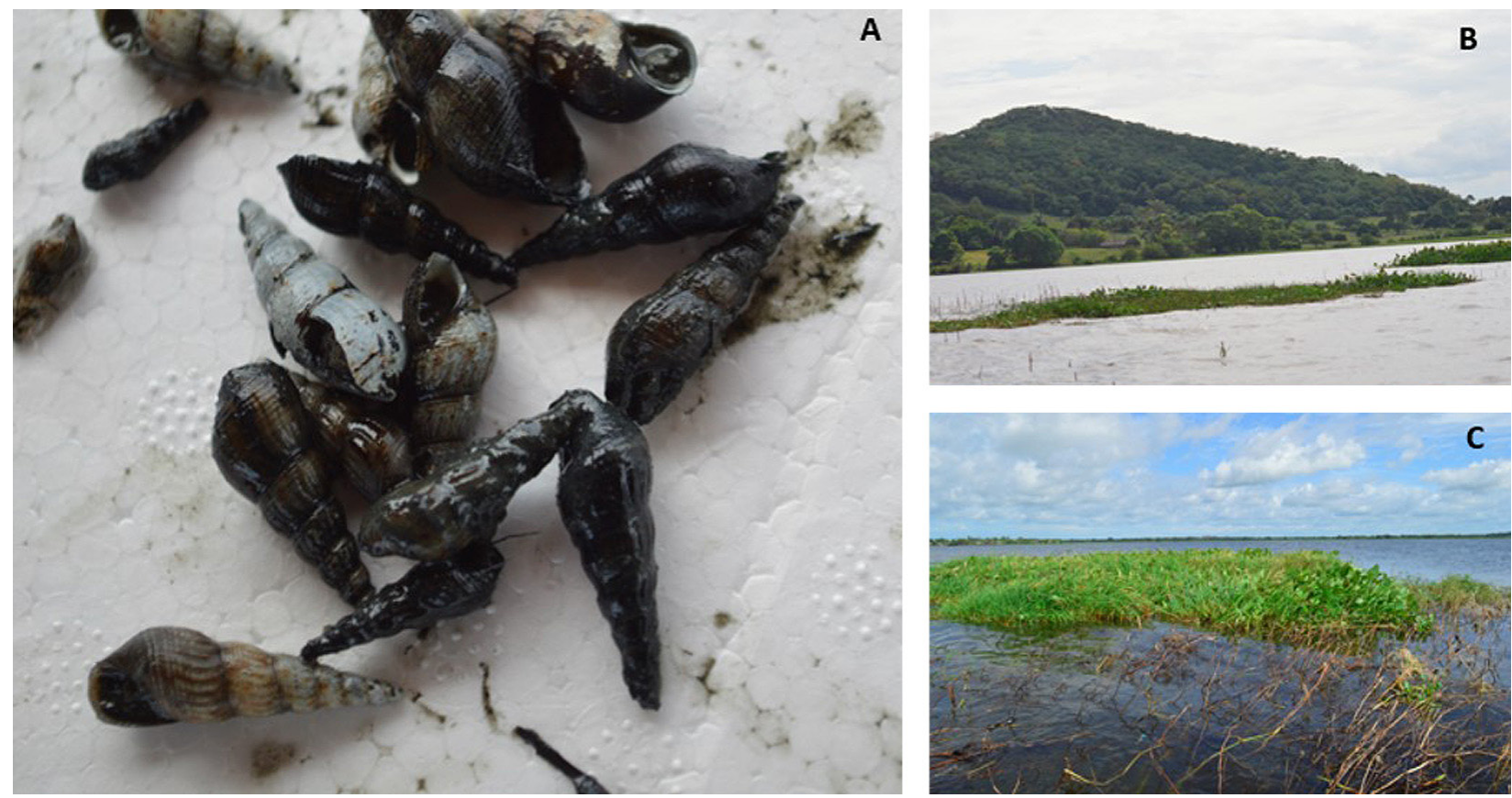

Figure 1. Melanoides tuberculata (Müller, 1774). A. Aggregate formed by individuals in the lower basin of the Sinú River, Córdoba. B. Momil. C. Purísima.

The goals of our research are to report the first record of the non-indigenous snail in the Colombian Caribbean, specifically in the lower basin of the Sinú River, to provide a description of its shell to alleviate a lack of previously published information on this species in Colombia, and to highlight the possible dispersal of this invasive species in the basin.

\section{Methods}

The lower basin of the Sinú River is a system of interconnected swamps located in the southwest of the Colombian Caribbean coast (Fig. 1B, C). The basin, covering an area of $336.68 \mathrm{~km}^{2}$, is located in the department of Córdoba. The Sinú River is the main water system in the region; this river fertilizes its valley, which is intensely used for agriculture and livestock. The Sinú River is part of one of the main ecosystems of the Colombian Caribbean coast. Along its course, the river has a complex connections with streams, marshes, and swamps that regulate its level during maximum flood periods (CVS 2009, Montoya and Aguirre 2009, Pérez-Vásquez et al. 2015). We recorded M. tuberculata at 4 localities of the basin: Caño de San Vicente, Los Corrales, Momil, and Purísima (Fig. 2). Fieldwork was first carried out at the rainy season in October 2016, and during the dry season in March 2017. In each locality, a line of $30 \mathrm{~m}$ perpendicular to the coast was extended, with 3 quadrants of $50 \mathrm{~cm} \times 50 \mathrm{~cm}$ placed every $10 \mathrm{~m}$ on the line. The specimens collected within the quadrants were stored in plastic bags, labeled, and fixed in $70 \%$ ethanol.

Voucher material of $M$. tuberculata was deposited in the Zoology Laboratory of the University of Córdoba (LZUC-MOL). Only individuals collected in each site for shell measurements were deposited as vouchers. Two shell measurements (length and width) were taken in the Microscopy Laboratory of the University of Córdoba, with an HD digital camera attached to the stereomicroscope Axiostar (Zeiss), and then assembled by the image stacking software AxioVision Rel.4.8.2. SP3 (Zeiss).

A 2-way ANOVA was used to test the differences among the average number of snails per locality and sampling season. The values were transformed prior to adding 0.5 to each value then using the square root transformation (Fowler et al. 1998). Post hoc testing was carried out using a Duncan's a posteriori test (Steel and Torrie 1985). All statistics were performed with STATGRAPHICS Centurion program (XV) 16.1.15 (Statpoint 2006). The spatial distribution of M. tuberculata was verified for each locality through the index of Morisita (Iס), with statistical significance verified by F-test (Ludwig and Reynolds 1988), where values of $I \delta=1$ indicate random distribution, $I \delta>1$ an aggregated distribution and $\mathrm{I} \delta<1$ a uniform distribution pattern.

Distribution maps were made using QGIS 3.0.2. Longitude and latitude were obtained from the implementation of primary and secondary information. Localities of specimens were plotted on a global land projection using OpenStreetMap (OSM).

\section{Results}

Class Gastropoda Cuvier, 1795

Order Caenogastropoda Cox, 1960

Family Thiaridae Gill, 1871 (1823)

Genus Melanoides Olivier, 1804

\section{Melanoides tuberculata (Müller, 1774)}

Figure 3 


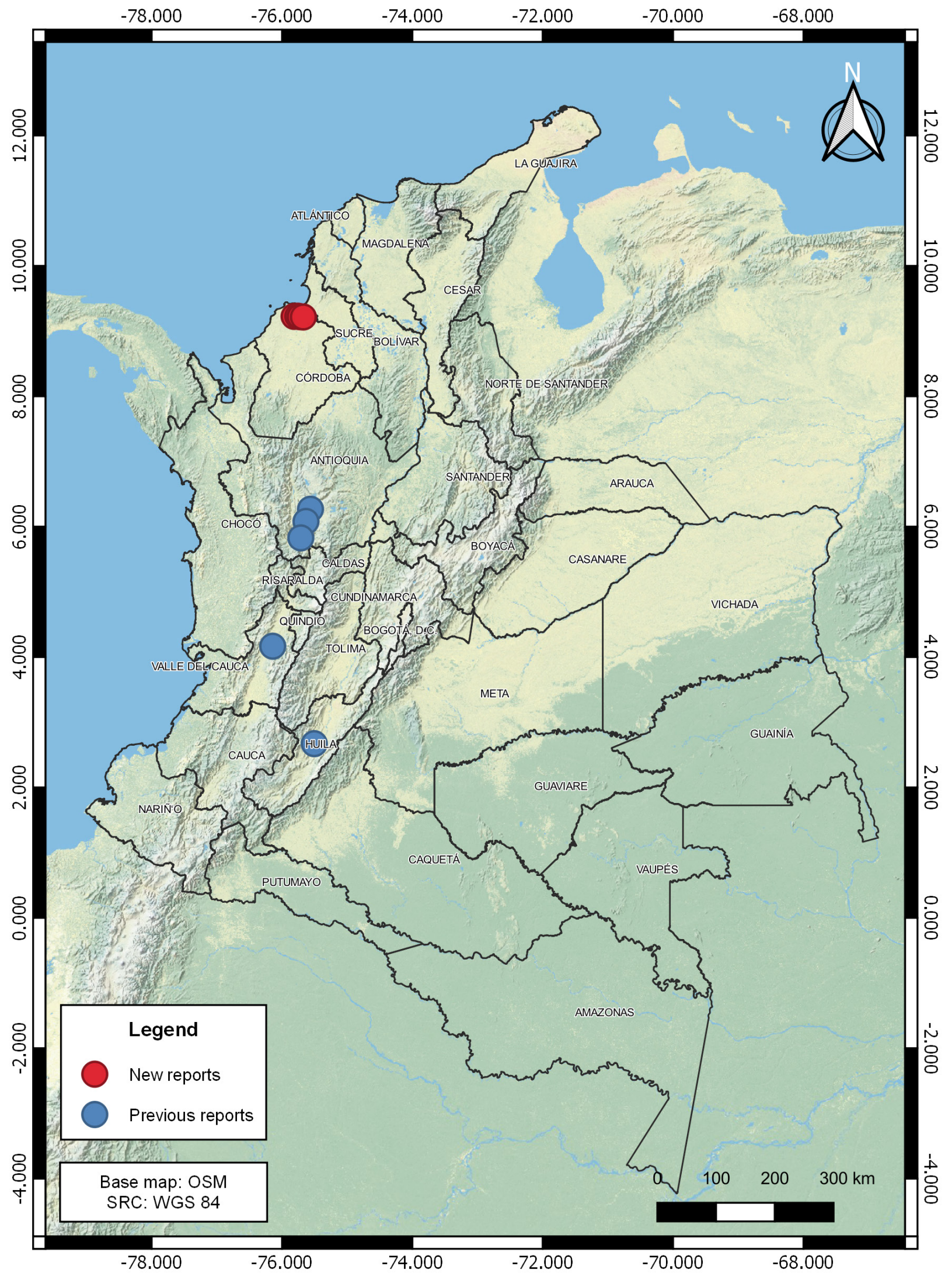

Figure 2. Distribution of Melanoides tuberculata in Colombia: blue circle = previous records; red circle = new records.

New records. Colombia: Córdoba: Lorica, Caño de San Vicente $\left(09^{\circ} 13^{\prime} 44^{\prime \prime} \mathrm{N}, 075^{\circ} 48^{\prime} 52^{\prime \prime} \mathrm{W}\right.$, elevation $\left.7 \mathrm{~m}\right)$, Juan Yepes-Escobar, 18-X-2016 (8 individuals, mean shell length $=6.12 \mathrm{~mm}$, mean shell width $=1.78 \mathrm{~mm}$, LZUC-MOL00101); Purísima, Los Corrales (09¹3'49"
$\mathrm{N}, 075^{\circ} 45^{\prime} 29^{\prime \prime} \mathrm{W}$, elevation $\left.7 \mathrm{~m}\right)$, Juan Yepes-Escobar, 21-X-2016 (8 individuals, mean shell length $=10.17$ $\mathrm{mm}$, mean shell width $=3.21 \mathrm{~mm}$, LZUC-MOL00102); Purísima, Ciénaga Massi $\left(09^{\circ} 13^{\prime} 26^{\prime \prime} \mathrm{N}, 075^{\circ} 43^{\prime} 19^{\prime \prime} \mathrm{W}\right.$, elevation $7 \mathrm{~m}$ ), Juan Yepes-Escobar and Jorge Quirós- 


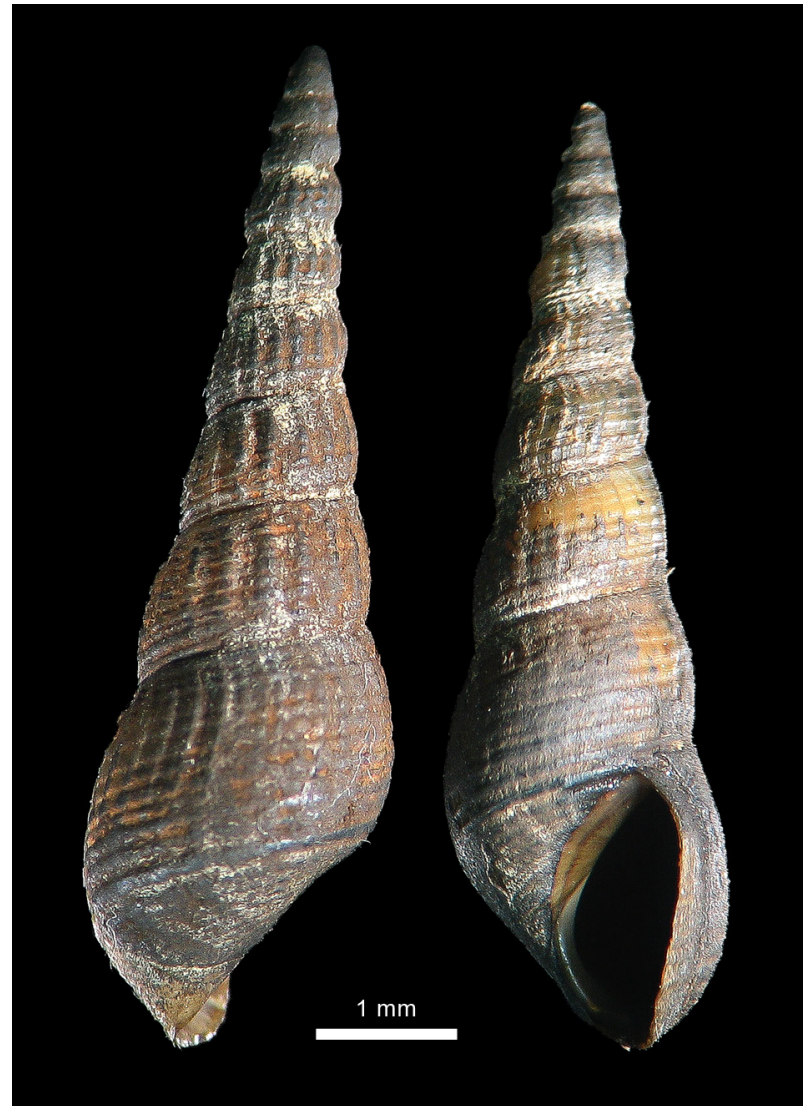

Figure 3. Shells of Melanoides tuberculata (Müller, 1774) (LZUCMOL00104) from the lower basin of the Sinú River, Córdoba, Colombia (scale bar $=1 \mathrm{~mm}$ ).

Rodríguez, 4-III-2017 (12 individuals, mean shell length $=21.23 \mathrm{~mm}$, mean shell width $=6.27 \mathrm{~mm}$, LZUCMOL00103); Momil, Playón de Momil (09¹3'07" N, $075^{\circ} 40^{\prime} 28^{\prime \prime} \mathrm{W}$, elevation $18 \mathrm{~m}$ ), Jorge Quirós-Rodríguez, 11-III-2017 (10 individuals, mean shell length $=19.46$ $\mathrm{mm}$, mean shell width $=6.13 \mathrm{~mm}$, LZUC-MOL00104)

Previous records in Colombia. Medellín Botanical Garden, Antioquia (Areiza et al. 2000, Velásquez et al. 2006, Vergara and Velásquez 2009), La Tablaza, Antioquia (Escobar et al. 2009), La Ardita, Puente Iglesias, Antioquia (Escobar et al. 2009), Yaguará, Huila (Linares and Vera 2012) and Andalucía, Valle del Cauca (Linares and Vera 2012).

Identification. The conchological characters of the individuals examined agree with the descriptions provided by Samadi et al. (1999: 1146), Facon et al. (2003: fig. 4A), Thompson (2004: fig. 43), and Santos et al. (2012: figs $17 \mathrm{~A}, \mathrm{~B}, 18)$.

Description. The shell of $M$. tuberculata is dextral, elongate, with length being greater than twice the width, and sculptured by spiral grooves. Shells of live specimens are predominantly dark brown, with a reddish-brown base. Because of the colour of the base, this species is commonly known as the Red-rimmed Melania (Duggan 2002). The Sinú River basin population has both juvenile and adult individuals. The mean shell length of individu-

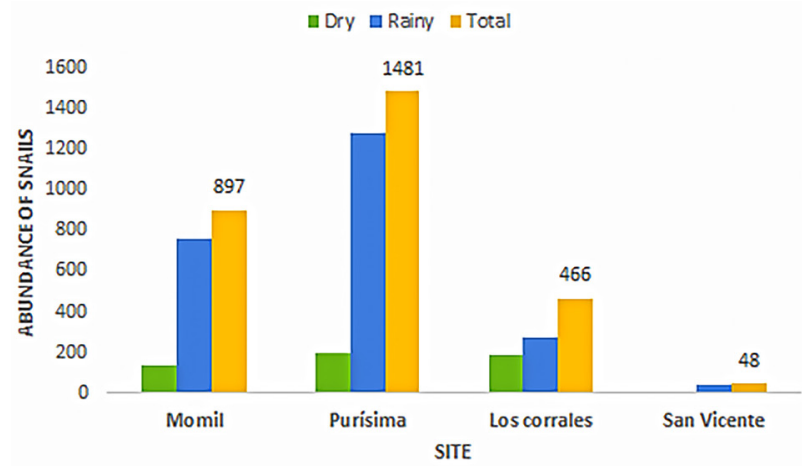

Figure 4. Abundance of snails per site and season in the lower basin of the Sinú River, Córdoba, Colombia: green bar = dry; blue bar = rainy; yellow bar $=$ total.

als from the lower basin of the Sinú River was $14.24 \mathrm{~mm}$ $(N=38$; minimum $=4.82 \mathrm{~mm}$, maximum $=22.49 \mathrm{~mm})$ while the mean shell width of specimens was $4.34 \mathrm{~mm}$ $(\mathrm{N}=38 ; \min =1.47 \mathrm{~mm}, \max =6.83 \mathrm{~mm})$.

Population size. We counted the greatest number of individuals in Purísima (1,481 individuals), followed by Momil (897), Los Corrales (466), and San Vicente (48) (Fig. 4). The greatest abundance was recorded in the rainy season (2,358 individuals), while the lowest abundance occurred in the dry season (534 individuals).

Statistically significant differences were established based on the average number of snails, in the study sites (ANOVA; $F=3.14, p=0.04$ ) and the months of sampling (ANOVA; $F=6.96, p=0.01$ ). Duncan's a posteriori test $(p<0.05)$ showed that mean abundance of M. tuberculata at Purisima, Momil and Los Corrales stations was significantly higher than those at San Vicente, which seems to indicate that the population of this snail is segregated by the flow of water and habitat of the lower basin of the Sinú River. By applying the Morisita Index, we found that the values varied between 1.02 in San Vicente and 3.89 in Purísima, revealing the aggregative characteristic of this species.

\section{Discussion}

Melanoides tuberculata is an epifaunal gastropod that is dominant on soft mud or sand substrates in shallow slow-flowing bodies of water (Da Silva et al. 1994). It exhibits clear phenotypic plasticity and is reported from a wide range of environmental conditions. It shows high resistance to pollution and other harsh conditions (Pointier et al. 1993, Vogler et al. 2012, Santos et al. 2012). The aquarium trade plays an important role in the dispersal of bioinvaders (Cowie and Robinson 2003, Gutiérrez-Gregoric and Vogler 2010) and was probably the gateway for this gastropod in the Sinú River basin. Several studies emphasize that $M$. tuberculata is capable of displacing native gastropods and even bivalves (Hershler 1998, Rader et al. 2003, Peso et al. 2010). Roessler et al. (1977) found that the growth and reproduction of Neritina virginea (Linnaeus, 1758) declined 
in the presence of $M$. tuberculata, presumably because of resource competition.

In contrast to Purísima and Momil, we found the abundance of $M$. tuberculata to be very low at San Vicente; the populations are not found permanently established here and are probably brought down to this area by the currents during the rainy season. The ability of $M$. tuberculata to resist displacement by rapid currents has not been measured. However, Pointier et al. (1994) found that this snail is uncommon in fast-flowing rivers in Venezuela. Other authors have observed that M. tuberculata can reach high densities in ponds and gently flowing waters (Miyahira et al. 2009). Although this species was abundant in a swiftly flowing canal in Louisiana, it primarily occurred in macrophyte beds where current was reduced (Dundee and Paine 1977). High abundances and in particular the environmental tolerance of adults (Pereda et al. 1990, Burlakova et al. 2010) can ensure the persistence of $M$. tuberculata in the basin. It is suggested that the mode of reproduction and the type of embryo development, which possibly play a very significant role in the spread and establishment of this species, would also affect its population dynamics (Ben-Ami and Hodgson 2005, Miranda et al. 2011). The clustered distribution of $M$. tuberculata was maintained in the 2 periods of the year with similar I $\delta$ values, which shows that seasonality does not affect the spatial distribution pattern for this species, which is comparable to other studies (Iannacone et al. 2003, Albarrán-Melze et al. 2009).

We recommend that the monitoring and control of M. tuberculata in the basin of the Sinú River, to assess this species' potential for establishing populations and the associated consequences of its presence on the river system. An understanding of the population dynamics of this species is important for predicting its interaction with the environment and determining the best control strategy (Burlakova et al. 2010). Habitats that have already been invaded by $M$. tuberculata present opportunities to learn how M. tuberculata interact with the environment (Miranda et al. 2011). Likewise, ecological studies are necessary to understand the invasive behavior and impacts of this species in newly invaded areas of Colombia.

\section{Acknowledgements}

We thank the Association of Producers for Community Development of Cienaga Grande del Bajo Sinú (ASPROCIG) for warning about the presence of the invasive snail in the basin, Juan Vergara for designing the map for this document, and Carlos Nisperuza Perez and Maira Acosta Berrocal for the collaboration in the collection and photographing of the specimens. We also thank the Microscopy Laboratory of the University of Cordoba for providing its facilities for the identification of the material collected.

\section{Authors' Contribution}

All authors contributed to the drafting and editing of the manuscript. JQ and JY participated in the data collection. JQ and GS identified the species.

\section{References}

Albarrán-Melze NC, Rangel-Ruiz LJ, Gamboa Aguilar J (2009) Distribution and abundance of Melanoides tuberculata (Gastropoda: Thiaridae) in the Biosphere reserve of Pantanos de Centla, Tabasco, Mexico. Acta Zoológica Mexicana 25 (1): 93-104.

Areiza A, Vélez I, Velásquez LE (2000) Melanoides tuberculata (Müller, 1774), in Colombia, an epidemiological risk? In: XVth International Congress for Tropical Medicine and Malaria, Cartagena, Colombia, 94.

Ben-Ami F, Hodgson AN (2005) Ovoviviparity and the structure of the brood pouch in Melanoides tuberculata (Gastropoda: Prosobranchia: Thiaridae). Journal of Morphology 263: 322-329. https://doi. org/10.1002/jmor.10307

Brown DS (1994) Freshwater Snails of Africa and their Medical Importance. Taylor \& Francis, London, 608 pp.

Burlakova LE, Padilla DK, Karatayev AY, Hollas DN, Cartwright LD, Nichol KD (2010) Differences in population dynamics and potential impacts of a freshwater invader driven by temporal habitat stability. Biological Invasions 12: 927-941. https://doi.org/10.1007/ s10530-009-9513-5

Corporación Autonoma y Regional de los Valles del Río Sinú y del San Jorge: CVS (2009) Plan de manejo y ordenamiento ambiental del complejo cenagoso del Bajo Sinú. CVS, Medellín, Colombia, 232 pp.

Cowie RH, Robinson DG (2003) Pathways of introduction of nonindigenous land and freshwater snails and slugs. In: Ruiz GM, Carlton JT (Eds) Invasive Species: Vectors and Management Strategies. Island Press, Washington, 93-122.

Da Silva RE, Melo AL, Pereira LH, Frederico LF (1994) Levantamento malacológico da bacia hidrografica do Lago Soledade, Ouro Branco (Minas Gerais, Brasil). Revista do Instituto de Medicina Tropical de Sao Paulo 36 (5): 437-444. https://doi.org/10.1590/ S0036-46651994000500008

Duggan C (2002) First record of a wild population of the tropical snail Melanoides tuberculata in New Zealand natural waters. New Zealand Journal of Marine and Freshwater Research 36 (4): 825-829. https://doi.org/10.1080/00288330.2002.9517135

Dundee DS, Paine A (1977) Ecology of the snail Melanoides tuberculata (Müller), intermediate host of the human liver fluke (Opisthorchis sinensis) in New Orleans, Louisiana. The Nautilus 91 (1): 17-20.

Escobar JS, Correa AC, David P (2009) Did life history evolve in response to parasites in invasive populations of Melanoides tuberculata? Acta Oecologica 35 (5): 639-644. https://doi.org/10.1016/j. actao.2009.06.001

Everett RA (2000) Patterns and pathways of biological invasions. Trends in Ecology \& Evolution 15 (5): 177-178. https://doi.org/10.1016/ S0169-5347(00)01835-8

Facon B, Pointier JP, Glaubrecht M, Poux C, Jarne P, David P (2003) A molecular phylogeography approach to biological invasions of the New World by parthenogenetic thiarid snails. Molecular Ecology 12 (11): 3027-3039. https://doi.org/10.1046/j.1365-294X.2003.01972.x

Fowler J, Cohen L, Jarvis P (1998) Practical Statistics for Field Biology. John Wiley \& Sons, Chichester, 272 pp.

Gutiérrez-Gregoric DE, Vogler RE (2010) Riesgo de establecimiento del gasterópodo dulceacuícola invasor Melanoides tuberculatus (Thiaridae) en el Río de la Plata (Argentina-Uruguay). Revista Mexicana de Biodiversidad 81 (2): 573-577. https://doi.org/10.22201/ ib.20078706e.2010.002.241

Hershler, R. 1998. A systematic review of the hydrobiid snails (Gastropoda: Rissooidea) of the Great Basin, western United States. 
Part I. Genus Pyrgulopsis. The Veliger 41 (1): 1-132.

Iannacone J, Mansilla J, Ventura K (2003) Macroinvertebrados en las lagunas de Puerto Viejo en Lima, Perú. Ecología Aplicada 2 (1): $116-124$.

Ladd HLA, Rogowski DL (2012) Egg predation and parasite prevalence in the invasive freshwater snail, Melanoides tuberculata (Müller, 1774) in a west Texas spring system. Aquatic Invasions 7 (2): 287-290. https://doi.org/10.3391/ai.2012.7.2.016

Leung B, Lodge DM, Finnoff D, Shogren JF, Lewis MA, Lamberti G (2002) An ounce of prevention or a pound of cure: Bioeconomic risk analysis of invasive species. Proceedings of Royal Society B: Biological Sciences 269 (1508): 2407-2413. https://doi. org/10.1098/rspb.2002.2179

Linares EL, Vera ML (2012) Catálogo de los moluscos continentales de Colombia. Biblioteca José Jerónimo Triana No 23. Universidad Nacional de Colombia. Facultad de Ciencias, Instituto de Ciencias Naturales, Bogotá D.C., 360 pp.

Ludwig JA, Reynolds JF (1988) Statistical Ecology: A Primer on Methods and Computing. John Wiley \& Sons, New York, 368 pp.

Miranda NAF, Perissinotto R, Appleton CC (2011) Population structure of an invasive parthenogenetic gastropod in coastal lakes and estuaries of northern KwaZulu-Natal, South Africa. PLoS ONE 6 (8): e24337. https://doi.org/10.1371/journal.pone.0024337

Miyahira IC, Lacerda LEM, Santos SB (2009) Dispersão ativa de (Müller, 1774) e sua influência no processo de invasão. Infomativo SBMa 40 (167): 3-5.

Montoya Y, Aguirre N (2009) Estado del arte de la limnología de lagos de planos inundables (Ciénagas) en Colombia. Gestión y Ambiente 12 (3): 85-105.

Perera G, Yong M, Ferrer JR, Arrinda C, Amador O (1990) Effectiveness of three biological control agents against intermediate host of snail-mediated parasites in Cuba. Malacological Review 23 (1-2) 47-52.

Pérez-Vásquez N, Arias-Ríos J, Quirós-Rodríguez J (2015) Variación espacio-temporal de plantas vasculares acuáticas en el complejo cenagoso del bajo Sinú, Córdoba, Colombia. Acta Biologica Colombiana 20 (3): 155-165. https://doi.org/10.15446/abc.v20n3.45380

Peso JG, Pérez DC, Vogler RE (2010) The invasive snail Melanoides tuberculata in Argentina y Paraguay. Limnologica. Ecology and Management of inland waters 41 (4): 281-284. https://doi org/10.1016/j.limno.2010.12.001

Pino J, López F, Iannacone J (2010) Impacto ambiental en la proporción de especímenes machos en poblaciones partenogenéticas de Melanoides tuberculata (Müller, 1774) (Prosobranchia: Thiaridae) en Perú. The Biologist 8 (2): 139-149.

Pinto HA, Melo AL (2010) Melanoides tuberculata as intermediate host of Philophthalmus gralli in Brazil. Revista do Instituto de Medicina Tropical de Sao Paulo 52 (6): 323-327. https://doi.org/10.1590/ S0036-46652010000600007

Pointier JP, Theron A, Borel G (1993) Ecology of the introduced snail Melanoides tuberculata (Gastropoda: Thiaridae) in relation to Biomphalaria glabrata in the marshy forest zone of Guadeloupe, French West Indies. Journal of Molluscan Studies 59 (4): 421-428. https://doi.org/10.1093/mollus/59.4.421

Pointier JP, Incani RN, Balzan C, Chrosciechowski P, Prypchan S
(1994) Invasion of the rivers of the Littoral Central Region of Venezuela by Thiara granifera and Melanoides tuberculata (Mollusca: Prosobranchia: Thiaridae) and the absence of Biomphalaria glabrata, snail host of Schistosoma mansoni. The Nautilus 107 (4): 124-128.

Pointier JP, Samadi S, Jarne P, Delay B (1998) Introduction and spread of Thiara granifera (Lamarck, 1822) in Martinique, French West Indies. Biodiversity and Conservation 7 (10): 1277-1290. https:// doi.org/10.1023/A:1008887531605

Rader RB, Belk MC, Keleher MJ (2003) The introduction of an invasive snail (Melanoides tuberculata) to spring ecosystems of the Bonneville Basin, Utah. Journal of Freshwater Ecology 18 (4): 647-657. https://doi.org/10.1080/02705060.2003.9664007

Roessler MA, Beardsley GL, Tabb DC (1977) New records of the introduced snail, Melanoides tuberculata (Mollusca: Thiaridae) in south Florida. Florida Scientist 40 (1): 87-94.

Samadi S, Mavárez J, Pointier JP, Delay B, Jarne P (1999) Microsatellite and morphological analysis of population structure in the parthenogenetic freshwater snail Melanoides tuberculata: insights into the creation of clonal variability. Molecular Ecology 8 (7): 1141-1153. https://doi.org/10.1046/j.1365-294x.1999.00671.x

Santos SB, Thiengo SC, Fernandez MA, Miyahira IC, Gonçalves ICB, Ximenes RF, Mansur MCD, Pereira D (2012) Espécies de moluscos límnicos invasores no Brasil. In: Mansur MCD, Santos CP, Pereira D, Paz ICP, Zurita MLL, Rodriguez MTR, Nehrke MV, Bergonci PEA (Eds) Moluscos límnicos invasores no Brasil: biologia, prevenção e controle. Redes Editora, Porto Alegre, 25-50.

Statpoint (2006) STATGRAPHICS ${ }^{\circledR}$ Centurion XV. Statistical Exploration and Modeling Software. https://www.statgraphics.net. Accessed on: 2018-05-21.

Steel R, Torrie J (1985) Bioestadística: Principios y procedimientos. McGraw-Hill, Bogotá, Colombia, 622 pp.

Thompson FG (2004) An Identification Manual for the Freshwater Snails of Florida. Florida Museum of Natural History, Gainesville, 89 pp. https://www.floridamuseum.ufl.edu/malacology/fl-snail/ snails1.htm. Accessed on: 2017-11-14.

Velásquez LE, Bedoya J, Areiza A, Vélez I (2006) First record of Centrocestus formosanus (Digenea: Heterophyidae) in Colombia. Revista Mexicana de Biodiversidad 77 (1): 119-121. https://doi. org/10.22201/ib.20078706e.2006.001.326

Vergara D, Velásquez LE (2009) Larvas de digenea en Melanoides tuberculata (Gastropoda: Thiaridae) en Medellín, Colombia. Acta Biologica Colombiana 14 (1): 135-142. https://doi.org/10.15446/ abc

Villadiego J. Huffman-Schwocho D, Guerrero S, Rivero S, Cortecero A (2015) Valoración ambiental para la generación de un modelo participativo de educación no formal. Luna Azul 41 (2): 165-478. https://doi.org/10.17151/luaz.2015.41.10

Vitousek PM, D’Antonio CM, Loope LL, Westbrooks R (1996) Biological invasions as global environmental change. American Scientist 84: 468-478.

Vogler RE, Núñez V, Gutiérrez-Gregoric DE, Beltramino AA, Peso JG (2012) Melanoides tuberculata: the history of an invader. In: Hamalainen, EM, Jarvinen S. (Eds) Snails: Biology, Ecology and Conservation. Nova Science Publishers, Inc, New York, 64-84. 